\title{
6.2 Штучний інтелект: що змінилося за 50 років
}

Науково-технічний прогрес не стоїть не місці. Розвиток систем штучного інтелекту (Artificial Intelligence), даталогії (Data Science)та машинного навчання (Machine Learning) вже сьогодні дозволяє людству робити те, що раніше могли уявити лише фантасти у своїх художніх творах: розпізнавання зображень та мови, ідентифікація особистості, прийняття надскладних рішень, прогнозування уподобань та поведінки людини, автокерування транспортом, побудова універсальних маршрутів тощо.

Діджиталізація як цифрова трансформація повсякденних речей настільки міцно увійшла в наше життя, що ще у 2001 році був введений новий показник рівня розвитку країн світу - індекс цифрової готовності NRI (Networked Readiness Index), який призваний охарактеризувати ступінь розвитку інформаційно-комунікаційних систем відповідної країни та $\epsilon$ важливим показником іiї розвитку і перспективності для інвестицій.

Все частіше в еру цифровізації науковці погоджуються 3 видатним афоризмом Натана Ротшильда: «Хто володіє інформацією - володіє світом». Вже зараз для керування людьми більше немає необхідності у тому, щоб мати велику армію підданих чи залучати для контролю спеціальні види репресій. За можливості безмежного доступу до інформації та засобів іiі обробки керування думками людей стає все простішим. Це в свою чергу є першим кроком до підриву соціальних свобод особистості та недоторканності приватного життя.

Але, перш ніж говорити про перспективи чи недоліки використання сучасних систем штучного інтелекту (візьмемо для прикладу саме їх),для початку треба чітко визначити для себе, що ми будемо вважати такими системами. Що саме роблять ті чи інші технічні системи, власне, інтелектуальними?Як відомо, термін «штучний інтелект» було введено ще у 1956 році видатним американським математиком Джоном МакКарті (John McCarthy). Так, у своїй роботі «Що таке штучний інтелект?» [345]. Мак Карті 
зазначав, що слово «інтелект» відповідає за деяку обчислювальну складову здатності досягати своєї цілі. Але тут одразу виникає питання, чи все те, що досягає певної цілі, можна назвати інтелектуальним? Сьогодні більшість дослідників при спробі визначити, що ж таке «штучний інтелект», рухаються у напрямку відтворення діяльності людського мозку за допомогою технічних засобів; але саме в такому формулюванні напрямку міститься велика кількість проблем.

Якщо детально зануритися в принцип роботи штучного інтелекту на прикладі нейронних мереж, можна сказати, що,взагалі, це - ускладнена версія дерева прийняття рішень з заздалегідь прописаними правилами та величезною базою знань. Чи можемо ми насправді вважати таку систему інтелектуальною? Чи, може, це просто більш досконала версія автоматизації прийняття рішень? На цьому моменті слід зауважити, що сучасні системи штучного інтелекту вже давно є самонавченими. Але зазначимо і те, що ті алгоритми, за допомогою яких сучасні нейронні мережі можуть «навчатися», в дійсності є спробою останніх, нехай і вдалою, відшукати певні закономірності між тими чи іншими явищами. А вже на основі цих логічних побудов вони працюють зі складними структурами даних. Отже, не слід забувати і той факт, що більшість систем з самонавчанням фактично пристосовані лише до певної області і при зміні сфери своєї діяльності є доволі низька ймовірність, що вони будуть демонструвати результат досить високого рівня.

Коли ми говоримо про самонавчання, так чи інакше розуміємо те, що існує хтось, хто передає певну інформацію до системи, i, як вже було неодноразово доведено у багатьох дослідженнях, таких, наприклад, як [346] і [347], отриманий результат буде у значній мірі залежати від початкових даних.

Більш того, окреме питання, яке виникає у зв’язку 3 повсюдним застосуванням штучного інтелекту, стосується алгоритмів роботи таких систем, адже ні для кого не секрет, що зі збільшенням розмірності та складності задач, які тепер здатні розв’язувати системи штучного інтелекту, чітко зрозуміти та логічно обгрунтувати їх роботу стає все менш можливим. Тобто на практиці ми 
маємо ситуацію, коли у реальності ніхто не в змозі оцінити ні логічність, ні правильність рішення системи штучного інтелекту через помірну складність задачі, і все, що залишається, зводиться до прийняття отриманих результатів на віру. Ця ситуація стає ще більш небезпечною з урахуванням тієї кількості рішень, які все частіше людство перекладає на машини. Чого варте одне американське дослідження використання системи COMPAS в сфері кримінального судочинства [348], в результаті непрозорості якої постійно відбувалися помилки в області визначення ймовірності скоєння злочину.

Взагалі, коли ми намагаємося пристосувати системи штучного інтелекту до будь-яких сфер, які хоч трохи стосуються питань етики чи моралі, одразу потрапляємо у пастку за принципом Юма, тим самим намагаючись перейти від «є» до «повинен». І це тільки одна невелика складова спроби повсюдного впровадження штучного інтелекту.

Саме на цьому етапі виникає резонне питання: чи для всіх сфер життєдіяльності ми, насправді, можемо застосувати системи штучного інтелекту на їх сучасному рівні розвитку? Здається, що ні. На практиці системи штучного інтелекту дуже добре зарекомендували себе у тих сферах діяльності, в яких можна побудувати чіткі алгоритми та математичні моделі, і в тих, де є великий об’єм даних та інформації, з чим людині буде складно працювати, але при цьому буде чітко визначена задача. Насправді, в цілій низці сфер діяльності, в яких неможливо конкретизувати задачу, іiі параметри, де необхідно працювати в умовах невизначеності, системи штучного інтелекту стикаються 3 рядом проблем на кшталт «катастрофічного забування» (catastrophic forgetting).

Зрозуміло, що цифровізація та системи штучного інтелекту значно прискорюють вирішення багатьох виробничих процесів і процесів прийняття рішень. Але ті масштаби, з якими зараз відбувається впровадження штучного інтелекту у всі сфери життя людини, в подальшому може призвести до глобального колапсу, пов'язаного з принципами демократії та можливостей соціально-психологічного пристосування людини. Доповнюючи дійсність людини віртуальною реальністю, вони не просто змінюють традиційні установки 
суспільства - створюють новий світ зі своїми правилами та законами, діючими всередині даного світу.

Ще одне питання стосується зміни самої природи людини. Шляхом звичайного відслідковування були підмічені дві досить чіткі тенденції,пов’язані 3 глобальними змінами. Перша 3 них - це намагання зробити штучний інтелект людяним, навчити його мислити як людина, відчувати як людина. Друга розвиток біоінженерії та намагання за допомогою сучасних технологій не тільки продовжити та покращити життя сучасної людини, а й «покращити», власне, саму людину. Відповідно до цього, найближчим часом, скоріш за все, виникне необхідність нового визначення, кого або що вважати людиною.

Коли ми кажемо про страхи перед штучним інтелектом, в першу чергу мова йде про одну 3 двох речей. Або ми говоримо про сингулярність та можливість штучного інтелекту в значній мірі перевершити здібності самої людини, а отже,стикаємося 3 неможливістю контролювати такі системи. Або ми говоримо про певну технічну революцію, результатом якої буде заміна людей на машини в усіх (або майже усіх) сферах діяльності, i тоді вже виникає питання щодо можливості та здатності людства в повній мірі змінити усталений впродовж століть спосіб життя.

У зв’язку з вищезазначеним виникає багато питань, які потребують розгорнутих відповідей. Наприклад, яким чином з урахуванням темпів розвитку технологій та цифровізації ми в змозі захистити свободу, рівність та конфіденційність кожного індивіда в світі інформаційних систем та технологій? Яким чином можна притримуватися основних принципів демократії 3 урахуванням підвищення впливу штучного інтелекту та машинного навчання на прийняття рішення? В якій мірі ми насправді можемо доручити машинам приймати рішення у тому випадку, коли питання стосується життя людей чи справедливості?Чи є раціональне та логічне рішення в дійсності справедливим? Чи готові ми довірити своє майбутнє сухій логіці та раціональності без можливості внесення в це майбутнє дещиці творчості і емоційної людяності? 
Якщо всі рішення будуть прийматися за нас розумними машинами, то що, власне, залишиться робити нам, людям?

Окрім низки соціальних та морально-етичних питань є також чимало питань, які йдуть з області права. Адже до сьогодні, з точки зору права, відсутній відповідний рівень міжнародної та національної нормативної основи використання штучного інтелекту на практиці.

Звичайно, концентруватися виключно на негативний стороні цифровізації та впровадження штучного інтелекту не є доцільним. В нас є цілий ряд причин, які спонукають рухатися назустріч штучному інтелекту та цифровізації.

I перша причина міститься безпосередньо у можливості того, що штучний інтелект перевершить людство в цілому ряді когнітивних здібностей на кшталт просторової орієнтації, швидкості обчислень, кількості інформації, які можна запам’ятати тощо. Зрозуміло, що така ситуація в першу чергу створить досить суттєву кризу в області працевлаштування, економіки. Але така криза та їі перспектива - перший крок до скорішого замислення над тим, хто є людиною та що відрізняє людину від «розумної» машини? Це - крок до нового осмислення себе та своєї ролі, крок до творчості, до поглиблення розуміння себе як особистості; в той самий час це - шлях до покращення соціальної взаємодії, поглиблення емоційного інтелекту, пошуку нових напрямків досліджень та пізнання особистості зокрема і суспільства в цілому. Це може призвести до встановлення нового розуміння гуманізму, альтруїзму, спільності, любові, єдності.

По-друге, розповсюдження та розростання штучного інтелекту, цифровізації може призвести до миттєвого стрибка в розвитку науки та знань. Наприклад, вже зараз ми є свідками кризи в області освіти, адже сучасні школи та виші, насправді, не встигають за тими темпами, 3 якими відбувається технічний прогрес. Усі розуміють необхідність фундаментальних змін, але тепер вже важко сказати, в якому напрямку дійсно необхідно рухатися для того, щоб та освіта, яку отримують сучасні школярі та студенти, була справді актуальною. Є надія, що саме розповсюдження всіляких технічних засобів, глобалізація та 
об’єднання вчителів і науковців допоможе розробити єдину загальну стратегію щодо подальшого напрямку розвитку наших звичних закладів освіти.

Окреме питання - наука. Вже зараз зрозуміло, що нові технічні системи допоможуть у майбутньому зробити велику кількість нових відкриттів в найрізноманітніших сферах науки, починаючи від фундаментальних складових матерії і закінчуючи вивченням Всесвіту. Така революція в області науки може значно розширити базу знань людства. Зрозуміло, що саме по собі таке розширення не говорить про покращення рівня життя, адже зі збільшенням можливостей пропорційно до цього збільшаться й вимоги до користувачів цими знаннями; але перспективи рівня розвитку науки при раціональному i ефективному використанні нової бази знань та відповідних освітніх систем навіть важко уявити.

Сучасний рівень технічних систем сьогодні дає майже безмежні можливості в плані співробітництва. Спільне навчання, взаємодія, об’єднання у великі професійні групи, об’єднання за інтересами, глибоке розуміння себе та світу через порівняння та взаємодію - це вже не фантазія, а реальність. I це є першим кроком до нового принципу самоорганізації.

Ще один крок у світле майбутнє - використання сучасних інформаційних та технологічних систем у медицині та біоінженерії. Довге та здорове життя - чи не про це ми всі мріємо для наших батьків та дітей, та для нас самих? 3 використанням сучасних технологій це все стає реальністю. Згадати хоча б ситуацію з пандемією covid-19, загрозу від якої вдалося знизити в немалій кількості саме завдяки сучасним технологіям.

Деякі науковці у своїх прогнозах зазначають [349], що у майбутньому повсюдне використання штучного інтелекту в сфері економіки призведе до суттєвого зниження економічних ризиків та небезпек. Факт впровадження інформаційних технологій, як передбачається, спричинить підвищення стабільності та стійкості фінансової системи.

У роботі Синиціної Ю.П. виконаної у співавторстві наведено результати дослідження можливостей нейромережевих методів прогнозування в 
інтелектуальній системі підтримки прийняття рішень у процесі управління підприємством [350]. Інтелектуальна система підтримки та прийняття рішень дасть змогу приймати найважливіші рішення в інтерактивному режимі, аналізувати, планувати і контролювати різні маркетингові заходи і проектувати їх за принципом «що, якщо». На цій основі з'являється можливість ієрархічного прийняття рішень. У результаті велике коло досить складних завдань, яке раніше могло виконуватися лише кваліфікованими фахівцями у сфері маркетингу, за допомогою систем підтримки рішень може бути реалізовано також фахівцями суміжних підрозділів [350].

В той же час у роботі [351] наведено результати дослідження можливостей практичних аспектів застосування нейронних мереж в аналізі макроекономічних показників підприємства на базі розробленого програмного продукту на основі нейромереж, який дає змогу прогнозувати макроекономічні показники за статистичними даними не тільки України, але й інших країн під час виходу підприємства на ці зовнішні ринки.

Найкращі прогнозні властивості для побудованої математичної моделі ІСППР демонструє генетичний алгоритм за використання радіально-базисних функцій. Створений програмний продукт дасть змогу моделювати та прогнозувати показники макросередовища як внутрішнього, так і зовнішнього ринку, на якому планує працювати підприємство [350, 351].

За деякими оцінками [352], використання штучного інтелекту здатне призвести до збільшення продуктивності праці на 37\% (в 2035 році), що стосується в першу чергу розвинених країн світу. Про зростання ролі штучного інтелекту в світі свідчить збільшення кількості венчурного капіталу, який припадає на долю систем штучного інтелекту, та збільшення економічного ефекту від використання у своїй роботи напрацювань штучного інтелекту [353, 354].

Ми живемо в складну епоху. Епоху, яка наповнена змінами. В своєму намаганні зазирнути в майбутнє та захистити себе ми знов і знов пробуємо спрогнозувати майбутнє. У 1967 році видатний американський вчений в області 
штучного інтелекту Марвін Лі Мінський сказав:«За період від трьох до восьми років ми отримаємо машину, порівнянну за загальним інтелектом з середньою людською істотою» [355]. Не дивлячись на виданий інтелект західного дослідника, він помилився, і навіть сьогодні, більш ніж через 50 років, ми все ще не наблизилися до створення «справжнього» штучного інтелекту. Так, в порівнянні з 60-ми роками, дійсно,людство зробило значний крок вперед у розвитку своїх технологій, але саме тепер від нас залежить, чи зможемо ми вірно скористатися нашим попереднім твором - для скорішого настання омріяного світлого майбутнього. Чи вистачить у нас розуміння, далекоглядності та проникливості для того, щоб повернути свій погляд в славне майбутнє та зробити одночасно обережні і вірні кроки у напрямку подальшого розвитку, а не бездумного збільшення виробничих потужностей та заробляння грошей? 